\title{
James Parkinson and his essay on "shaking palsy", two hundred years later
}

\author{
James Parkinson y su ensayo sobre la "parálisis agitante", doscientos años después \\ Leonardo Palacios-Sánchez', Martha Torres Nupan², Juan Sebastián Botero-Meneses ${ }^{1}$
}

\begin{abstract}
In 1817, British physician James Parkinson published a 66-page document entitled "Essay on the Shaking Palsy". This brief text became a classical and fundamental piece in the history of medicine and, in particular, of neurology. The authors of this article wish to pay tribute to this great pioneer of neurology, 200 years after the publication of his findings, which would, in turn, immortalize his name and give rise to the renaming on the entity in 1860 by Professor Jean Martin Charcot, father of neurology. It would be known, henceforth as Parkinson's disease.
\end{abstract}

Keywords: Parkinson; Charcot; history of medicine; neurology.

\section{RESUMEN}

En 1817 el médico británico James Parkinson publicó un documento de 66 páginas titulado “Ensayo sobre la parálisis agitante”. Este breve texto es de una gran importancia en la historia de la medicina y en particular de la neurología. Los autores desean rendir homenaje a este gran pionero de la neurología al cumplir doscientos años la publicación que inmortalizaría su nombre y que dio origen a la primera descripción de la entidad que desde 1860, a propuesta del profesor Jean Martin Charcot, el padre de la neurología, se denomina Enfermedad de Parkinson. (James - Hierons).

Palabras clave: Parkinson; Charcot; historia de la medicina; neurología.

James William Keys Parkinson was born on April 11, 1755 in the village of Hoxton in Middlesex, just north of London. Although the Hoxton Square home in which he grew up was demolished, a commemorative plaque has been placed in the $\operatorname{area}^{1}$. He came from a family of four generations of surgeons and apothecaries ${ }^{2,3}$. Son of Mary and John Parkinson, parents of three children, James was the eldest ${ }^{3}$, followed by his brother William and sister Mary. His father was an apothecary and surgeon, who was a member of the Company of Surgeons, working as a physician in the vicinity of Hoxton ${ }^{1,4}$.

After studying Latin, Greek, natural philosophy and shorthand, James Parkinson started his medical studies alongside his father and joined the Hospital of London in 1776, where he was a disciple of John Hunter (1794). He received a surgeon's diploma from the Company of Surgeons, the forerunner of the current Royal College of Surgeons, in 1784, only a few months after his father's death. He became a Fellow of the Medical Society of London in 1787, a founding member of the Medical - Surgical Society in 1812, as well as of the Hunterian Society in 1819 and received the gold medal of the Royal College of Surgeons in $1822^{2}$. He was also a prominent member of the Geological Society of London ${ }^{5}$. In addition to his work as a surgeon, he was deeply involved in the well-being of patients from numerous mental institutions located around Hoxton ${ }^{1}$.

His baptism, marriage and funeral honors took place in the chapel Saint Leonard in Shoredicht ${ }^{2}$.

\section{CONTRIBUTION TO THE EMERGING FIELD OF GEOLOGY}

James was a prolific author. His first publication dates from the year 1780 and is titled "Observations on Dr. Hugh Smith's Philosophy of Physic". His most famous book is a three-volume paleontological study called "Organic Remains of a Former World" (1804-1811). It was edited three times. His writings on medical subjects include: some accounts of the effects of lightning, a case of diseased vermiform appendix (possibly the first account of appendicitis), typhoid fever, hydrophobia, hints for the improvement of trusses, gout, and the Essay on the Shaking Palsy?

\footnotetext{
Universidad del Rosario, School of Medicine and Health Sciences, Neuroscience Research Group (Neuros), Neuroscience Department, Bogotá, Colombia; 2Universidad del Rosario, School of Medicine and Health Sciences, Bogotá Colombia.

Correspondence: Leonardo Palacios-Sánchez; Carrera 24 \# 63c-69, Universidad del Rosario, Quinta Mutis, School of Medicine and Health Sciences; E-mail: leonardo.palacios@urosario.edu.co 
In addition to his important contributions in the medical field, he was described by several as an individual with radical political views, a pacifist and an agitator for parliamentary reform. He wrote about social reform and was a member of two of London's leading societies promoting electoral reform: the London Corresponding Society and the Society for Constitutional Information. Membership to these societies was considered very controversial at that time, and their contributions were made under the pseudonym of Old Hurbert ${ }^{1,3}$.

For his involvement in the London Corresponding Society, he was implicated in the conspiracy scandal of the attempt to assassinate King George III. Parkinson was called before the Privy Council to declare his innocence and was directly questioned by Prime Minister William Pitt, the Younger. Finally, the allegations were withdrawn. After these events, Parkinson focused more on medicine and other scientific matters that contributed to various fields such as chemistry, geology and paleontology ${ }^{1}$.

He died on December 21, 1824 on Kingsland Road, very close to where he grew up. A commemorative plaque was placed at St Leonard's Church in 1955, the 200th anniversary of his birthday. Curiously, there is no painting of him in which his face or figure ${ }^{3}$ has been recorded. Frequently, two images have been erroneously attributed to James Parkinson - the images of James Parkinson (first treasurer of the British Dental Association) and James Cumine Parkinson ${ }^{5,6}$.

The paper entitled "Essay on the Shaking Palsy", published in 1817, is a 66-page text divided into five chapters in which it defines the condition, its pathognomonic characteristics, the differential diagnosis, the etiology and the treatment. It is based on his experience with six patients over several years. The eponymous title for this condition was given in 1860 at the proposal of Jean-Martin Charcot, who proposed the name "la maladie de Parkinson",7.

The first autopsy performed on a patient with Parkinson's disease was performed in $1861^{8}$.
In his essay, he emphasized the great impact of this disease on patients, which he described as follows:

"The unhappy sufferer has considered it an evil, from the domination of which he had no prospect of escape"

The remarkable definition he made of the disease differs from the current definition with the inclusion of non-motor symptoms as part of the clinical picture:

"Involuntary tremulous motion, with lessened muscular power, in parts not in action and even when supported; with a propensity to bend the trunk forwards, and to pass from a walking to a running pace: the senses and intellects being uninjured ${ }^{9}$.

James Parkinson also expressed great optimism about the possibility of finding a future treatment. Unfortunately, levodopa was only introduced as a symptomatic treatment 140 years later.

"There appears to be sufficient reason for hoping that some remedial process may be discovered, by which, at least, the progression of the disease may be stopped 9 "

In his essay he mentions Juncker's works, dividing tremors into "active - produced by sudden affections of the mind, terror or rage; and passive - secondary to debilitating conditions such as advanced age, paralysis, etc." ${ }^{3}$ He also makes reference to the works of Van Swieten (1749), who made similar observations on the tremor and Sauvages's contributions on the festinant gait $(1758)^{3}$.

The description of the cases was undoubtedly the basis for the birth of a new disease. However, it is important to note that two neurologists of the nineteenth century made very important contributions to give it identity: Jean Martin Charcot (1825 - 1893) and William Gowers (1845 - 1915) ${ }^{7}$.

Parkinson's disease is, nowadays, the most common neurodegenerative disease after Alzheimer's disease. It will carry the eponym of this great physician, humanist, social agent and British paleontologist who, with rigor and meticulous clinical observation, described it masterfully 200 years ago.

\section{References}

1. Lewis. 2012. James Parkinson: the manbehind the shaking palsy. J Parkinson Dis. 2012;2(3):181-7. https://doi.org/10.3233/JPD-2012-012108

2. James DG, Hierons R. Parkinson and his disease revisited. Postgrad Med J. 1991;67(785):227-9

3. Pearce JM. Aspects of the history of Parkinson's disease. J Neurol Neurosurg Psychiatry. 1989;52(Suppl):6-10.

4. Poirier J. [James Parkinson (1755-1824) revisited]. Geriatr Psychol Neuropsychiatr Vieil. 2013;11(1):65-72. French. https://doi.org/10.1684/pnv.2013.0386
5. Sakula A. Gentlemen of the Hammer: British medical geologists in the 19th century.J R Soc Med. 1990;83(12):788-94.

6. Stott SRW. The wrong James Parkinson. Pract Neurol. 2014;(2):148. https://doi.org/10.1136/practneurol-2014-001043

7. Hoen M. The natural history of Parkinson's disease in the pre-levodopa and post-levodopa eras. Neurol Clin. 1992;10(2):331-9.

8. Kapp W. The history of drugs for the treatment of Parkinson's disease. J Neural Transm Suppl. 1992;38:1-6.

9. Parkinson J. An essay on the shaking palsy.J Neuropsychiatry Clin Neurosci. 2002;14(2):223-36. https://doi.org/10.1176/jnp.14.2.223 